\title{
Effect of Antiepileptic Drugs on Plasma Carnitine Level in Children with Idiopathic Epilepsy
}

\author{
AHMED M. EL-NINY, M.Sc.; SAHAR A. ABD EL-AZIZ, M.D.; KHALED T. MUHAMMAD, M.D. and \\ HESHAM A. EL-SOROGY, M.D.
}

The Department of Pediatrics, Faculty of Medicine, Tanta University

\begin{abstract}
Background: Prolonged antiepileptic drugs treatment can result in secondary carnitine deficiency. Clinical studies indicate a decrease in total and free plasma carnitine level in children treated with old antiepileptic drugs especially valproate.
\end{abstract}

Aim of Study: Was to evaluate the plasma carnitine level in children with idiopathic epilepsy treated with old antiepileptic drugs (valproate and carbamazepine) and new antiepileptic drugs (leviteracetam and oxcarbazepine).

Patients and Methods: This study was a prospestive study including 50 patients with newly diagnosed idiopathic epilepsy classified into four groups according to their antiepileptic drug treatment into: Group 1, 20 patients received valproic acid. Group 2, 10 patients treated with carbamazepine. Group 3, 10 patients treated with leviteracetam. Group 4, 10 patients treated with oxcarbazepine. The study was carried out in duration of 1 year from January 2017 to January 2018.

Results: There was significant difference between mean plasma level of carnitine in children treated with valproate and the controls. There was inverse correlation between the duration of treatment with valproate and the mean plasma carnitine level. There was inverse correlation between the level of valproate and the mean plasma carnitine level. The higher the level of valproic acid, the more significant decrease in the mean plasma carnitine level.

Conclusion: Valproic acid was the only antiepileptic drug reported to cause carnitine deficiency. Also this study showed inverse correlation between plasma carnitine level and duration of treatment with valproic acid. The longer the duration of treatment, the more significant decrease in mean plasma carnitine level. Also, there was inverse correlation between the level of valproate and the mean plasma carnitine level. The higher the level of valproic acid, the more significant decrease in the mean plasma carnitine level.

Key Words: Valproate - Carnitine deficiency - Antiepileptic drugs.

Correspondence to: Dr. Ahmed M. El-Niny, The Department of Pediatrics, Faculty of Medicine, Tanta University

\section{Introduction}

PROLONGED antiepileptic drugs treatment can result in secondary carnitine deficiency. Clinical studies indicate a decrease in total and free plasma carnitine level in children treated with old antiepileptic drugs especially valproate [1].

Carnitine is a protein that is essential to the metabolism of long chain fatty acids that are metabolized in the mitochondria within the cell. Each molecule of fat has to be transported across the mitochondrial membrane by binding with a molecule of carnitine [2]

Carnitine deficiency is manifested as, encephalopathy; the patient may present limp, unresponsive and comatosed, myopathic presentation, the patient may have hypotonia or proximal muscle weakness. Cardiomyopathy has also been observed. Progressive cardiomyopathy usually manifests at an older age [3]

\section{Patients and Methods}

The study was carried out in Tanta University Hospital Pediatric Department, Neurology Unit. Fifty children with newly diagnosed idiopathic epilepsy selected from those attending the pediatric neurology outpatient clinic and enrolled in the study with patients classified into four groups according their antiepileptic drug treatment into: Group 1, 20 patients received valproic acid as momotherapy without any antiepileptic drug treatment before. Group 2, 10 patients treated with carbamazepine. Group 3, 10 patients treated with leviteracetam as monotherapy. Group 4, 10 patients treated with oxcarbazepine as monotherapy. Twenty healthy children served as control group with the 
same age range. The study was carried out in duration of 1 year from January 2017 to January 2018.

\section{Inclusion criteria:}

1-All the epileptic children had no history of liver, renal or metabolic disease or history of AEDs or carnitine intake before the study.

2- These patients with idiopathic epilepsy had no apparent cause of epilepsy such as structural problem in the brain or metabolic disorder.

3- Positive family history of epilepsy in most of cases.

4- Patients with normal brain Magnetic Resonance Imaging (MRI) study.

5- Normal intelligence.

\section{Exclusion criteria:}

1- Patients with symptomatic epilepsy.

2- Patients with liver or renal diseases.

3- Patients with hypotonia or progressive weakness.

All patients were subjected to complete history taking, thorough physical examination, magnetic resonance imaging, electroencephalogram and estimation of plasma level of carnitine before the start of treatment and after 6 momths of antiepileptic drug intake.

\section{Statistical analysis:}

Statistical presentation and analysis of the present study was conducted, using the mean, standard deviation, paired $t$-test, linear correlation coefficient and Analysis of variance [ANOVA] tests by SPSS V 17 .

1- Mean $=\frac{\Sigma \chi}{\mathrm{n}}$

Where:

$\Sigma=$ Sum.

$\mathrm{n}=$ Number of observations.

\section{2- Standard Deviation [SD]:}

$\mathrm{SD}=\sqrt{\frac{\sum \mid \mathrm{X}-\mathrm{X}^{2}}{\mathrm{n}-1}}$

Paired $t$-test:

$t=\frac{X d}{\sqrt{ }}$

\section{Where:}

$\overline{\mathrm{X}}=$ Mean's difference between pre and post.

SEd $=$ Standard error of the difference between pre and post.
Unpaired student $t$-test was used to compare between related sample.

Linear correlation coefficient $[r]$ :

$$
r=\frac{\Sigma(\mathrm{X}-\mathrm{X})(\mathrm{y}-\mathrm{y})}{\sqrt{\{\Sigma(\mathrm{X}-\mathrm{X}) 2\}\{\Sigma(\mathrm{y}-\overline{\mathrm{y}}) 2\}}}
$$

Where:

$\mathrm{X}=$ Independent variable.

$\mathrm{Y}=$ Dependent variable.

Linear correlation coefficient was used for detection of correlation between two quantitative variables in one group.

Analysis of variance [ANOVA] tests. According to the computer program SPSS for Windows. ANOVA test was used for comparison among different times in the same group in quantitative data.

$p$-value $>0.05$ Non significant.

$p$-value $\leq 0.05$ Significant.

$p$-value $<0.01$ Highly Significant.

\section{Results}

Table (1): Comparison between the mean plasma carnitine level in children with epilepsy and the control

\begin{tabular}{|c|c|c|c|c|c|}
\hline \multirow{2}{*}{ Groups } & \multicolumn{2}{|c|}{$\begin{array}{l}\text { Carnitine level } \\
(\text { al/L) }\end{array}$} & \multicolumn{2}{|c|}{ ANOVA } & \multirow{2}{*}{$\begin{array}{l}\text { Groups } \\
\text { and } \\
\text { controls }\end{array}$} \\
\hline & Range & Mean $\pm \mathrm{SD}$ & $\mathrm{F}$ & $p$-value & \\
\hline Valproate & $40-57$ & $47.600 \pm 5.605$ & 306.017 & $<0.001 *$ & $p 1<0.001 *$ \\
\hline Carbamazepine & $82-90$ & $87.200 \pm 2.936$ & & & $p 20.326$ \\
\hline Leviteracetam & $87-97$ & $93.000 \pm 3.528$ & & & $p 30.853$ \\
\hline Oxcarbazepine & $82-95$ & $89.400 \pm 4.600$ & & & $p 40.929$ \\
\hline Controls & $85-95$ & $91.000 \pm 3.590$ & & & \\
\hline
\end{tabular}
children after treatment.

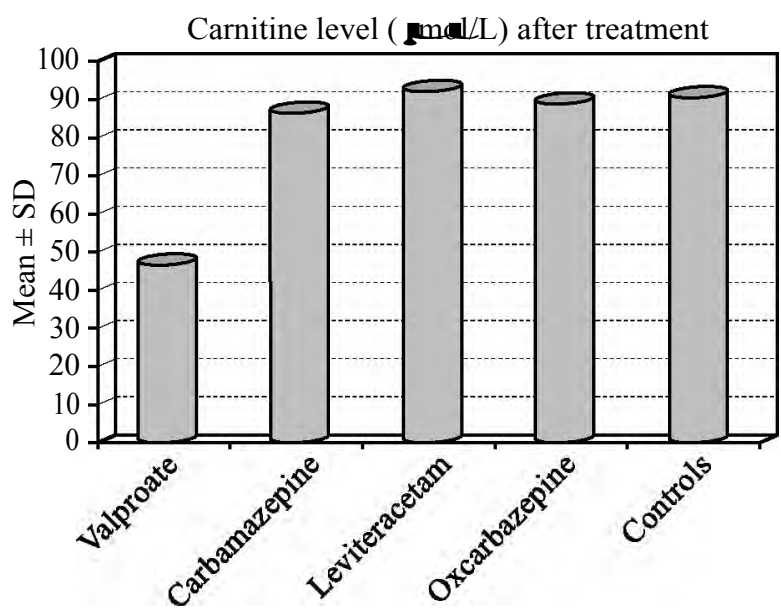

Fig. (1): Comparison between the mean plasma carnitine level in children with epilepsy and the control children after treatment.

Table (1) and Fig. (1) show that there was significant difference between mean plasma carnitine level in children treated with valproate after 
receiving treatment and the controls but there was no significant difference between mean plasma carnitine level in children treated with carbamazepine, leviteracetam and oxcarbazepine after receiving treatment and the controls.

Table (2): Comparison of the mean serum level of plasma carnitine level in children treated with valproic acid before and after treatment.

\begin{tabular}{|c|c|c|c|}
\hline Groups & $\begin{array}{l}\text { Carnitine } \\
\text { Before treatme }\end{array}$ & $\begin{array}{l}\mu \mathrm{mol} / \mathrm{L}) \\
\text { er treatment }\end{array}$ & $p$-value \\
\hline \multicolumn{4}{|l|}{ Valproate: } \\
\hline Range & $79-97$ & $40-57$ & $<0.001 *$ \\
\hline
\end{tabular}

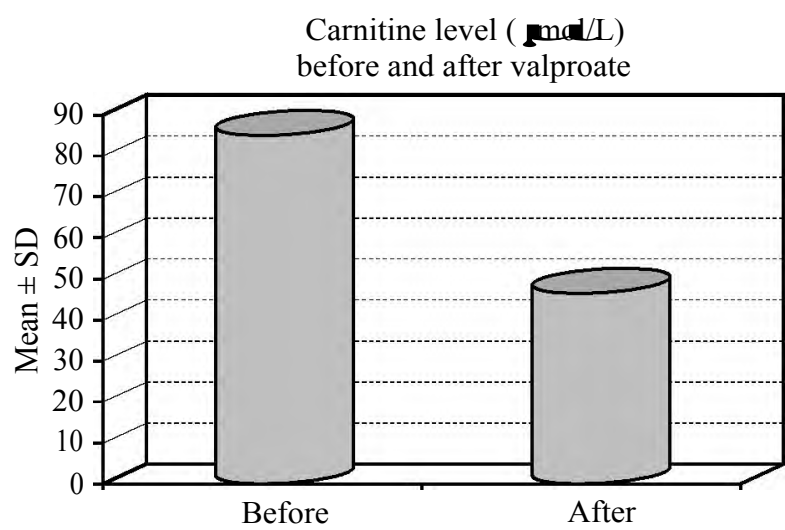

Fig. (2): Comparison of the mean serum level of plasma carnitine level in children treated with valproic acid before and after treatment.

Table (2) and Fig. (2) show that there was significant decrease in mean plasma carnitine level after treatment with valproate.

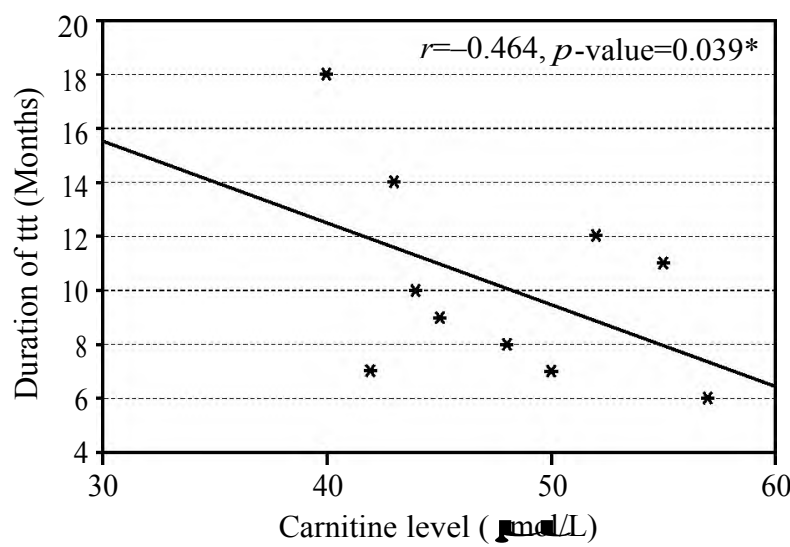

Fig. (3): Correlation between duration of treatment with valproate and carnitine level.

There was inverse correlation between the duration of treatment with valproate and the mean plasma carnitine level. The longer the duration of treatment, the more significant decrease in plasma carnitine level.

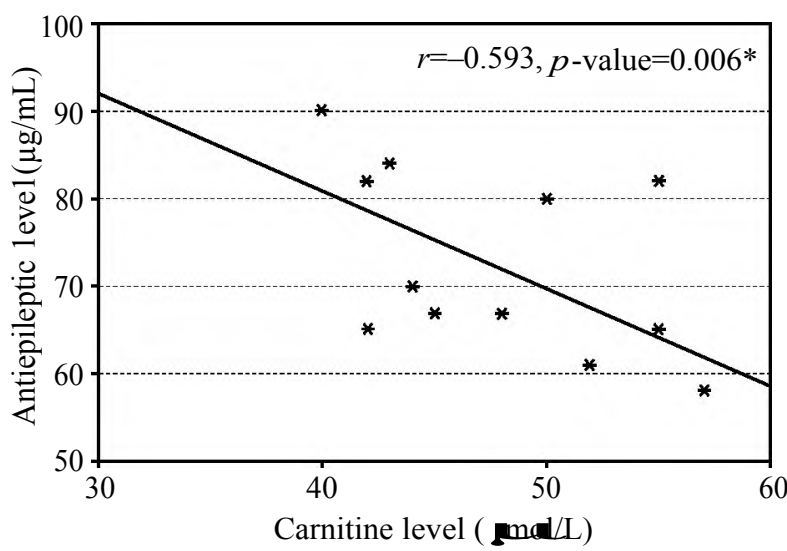

Fig. (4): Correlation between level of valproate and mean plasma carnitine level.

There was inverse correlation between the level of valproate and the mean plasma carnitine level. The higher the level of valproic acid, the more significant decrease in the mean plasma carnitine level.

\section{Discussion}

The results of this study agree with Qiliang et al., [4], who measured free carnitine and acylcarnitines levels in 299 children with epilepsy treated with valproate monotherapy between June 2014 and September 2015 were compared with age-and sex-matched 299 healthy controls. Results showed that children treated with valproate monotherapy had lower free carnitine levels than the controls.

Also, the results of this study agree with Nakamura et al., [5] who measured plasma total and free carnitine levels in four groups of children: Group (1) who treated with valproic acid as monotherapy $(n=43)$, Group (2) who treated with valproic acid plus other antiepileptics as polytherapy $(n=91)$, Group (3) who treated with other antiepileptic drugs alone ( $\mathrm{n}=43$ ), and Group (4) normal patients $(n=89)$. The mean free carnitine level was significantly lower in both the valproic acid monotherapy and polytherapy groups compared with normal subjects. Comparison of valproic acid polytherapy and monotherapy yielded significantly lower free carnitine levels in the polytherapy group.

The results of this study also agree with Cansu et al., [6] who measured serum concentrations of total carnitine, free carnitine and acylcarnitine in 56 epileptic children, 28 treated with valproic acid (Group 1), 28 treated with oxcarbazepine (Group 2 ) and 28 treated with leviteracetam (Group 3) and 28 healthy controls (Group c). Duration of treatment was 6-12 months in Groups 1, 2 and 3. Results showed lower carnitine level in children treated with valproic acid than controls while no significant 
difference in carnitine level between children treated with oxcarbazepine and controls.

The results of this study also agree with Murat et al., [7] who measured serum concentrations of total carnitine, free carnitine and acylcarnitine in 50 patients with epilepsy, 3 to 14 years of age, who were treated with valproate only for a mean of one year and free of abnormal neurologic findings or nutritional problems. The control group consisted of 30 healthy children. Results showed that children treated with valproate monotherapy had lower free carnitine levels than the controls.

The results of this study agree with Werner et al., [8] who measured serum carnitine longitudinally before and after therapy in 15 patients treated with valproic acid, 14 patients treated with carbamazepine and 20 healthy children. The patients who received valproic acid showed a significant reduction in free (and total) serum carnitine with valproic acid in comparion with controls. Such an effect was not found in patients treated with carbamazepine.

The results of this study also agree with Fung et al., [9] who measured serum concentrations of total carnitine, free carnitine and acylcarnitine in 43 children with epilepsy who were treated solely with valproate for a mean of 6 months. The control group consisted of 30 healthy children. Results showed that children treated with valproate monotherapy had lower free carnitine levels than the controls.

The results of this study agree with Semra kurel et al., [10] who studied serum concentrations of total and free carnitine in 20 healthy children, 20 children with epilepsy treated with oxcarbazepine monotherapy and 20 children with epilepsy who treated with carbamazepine as monotherapy. The assays were performed between 3 and 6 months of oxcarbazepine and carbamazepine treatment.

No significant difference was observed in the level of total and free carnitine levels between healthy group and epileptic chidren treated with carbamazepine and oxcarbazepine. Results suggest that neither oxcarbazepine nor carbamazepine as monotherapy causes carnitine deficiency in otherwise healthy children with primary idiopathic epilepsy.

\section{References}

1- RASKIND, JACKIE Y., EL-CHAAR and GLADYS M.: The role of carnitine supplementation during valproic acid therapy. Annals of Pharmacotherapy, 34: 630-8, 2000.

2- VAZ F.M. and WANDERS R.J.: Carnitine biosynthesis in mammals. Biochem. J., 361: 417-29, 2002.

3- FLANAGAN J.L., SIMMONS P.A., VEHIGE J., WILLCOX D.P. and GARRETT Q.: Role of carnitine in disease. Nutrition \& Metabolism, 7: 30-3, 2010.

4- QILIANG L., WENQI S. and HONG J.: Carnitine Deficiency in Chinese Children with Epilepsy on Valproate Monotherapy, 319: 87-13 5, 2018.

5- NAKMURA M. and NAGAMINE T.: The effect of carnitine supplementation on hyperammonemia and carnitine deficiency treated with valproic acid in a psychiatric setting. Innovations in Clinical Neuroscience, 12: 10-8, 2015.

6- CANSU A., SERDAROGLU A., BIBEROGLU G., TUMER L., HIRFANOGLU T.L., EZGU F.S., et al.: Analysis of acylcarnitine levels by tandem mass spectrometry in epileptic children receiving valproate and oxcarbazepine. Epileptic Disorders, 13: 394-400, 2011.

7- MURAT M., HELVACI M., OZBAL E., KALENDERER O. and DILEK M.: Serum and muscle carnitine levels in epileptic children receiving sodium valproate. Journal of Child Neurology, 24: 80-6, 2009.

8- WERNER T., TREISS I., KOHLMUELLER D., MEHLEM P., TEICH M., LONGIN E., et al.: Effects of Valproate on Acylcarnitines in Children with Epilepsy Using ESIMS/MS. Epilepsia, 48: 72-6, 2007.

9- FUNG E.L., TANG N.L., LAM C.W. and FOK T.F.: Carnitine level in Chinese epileptic patients taking sodium valproate. Pediatric Neurology, 28: 24-7, 2003.

10- KURUL S., DIRIK E. and IISCAN A.: Serum carnitine levels during oxcarbazepine and carbamazepine monotherapies in children with epilepsy. Journal of Child Neurology, 18: 552-4, 2003. 


\section{تآثير العلاج بالآدوية المضادة اللصرع على مستوى مادة الكارنيتين بالبلازما

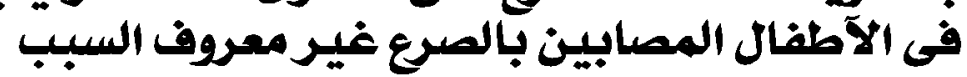

إن إستخدام آدوية علاج الصرع لفترة طويلة قد ينتج عنه نقص مادة الكارنيتين وقد وجد آن الدراسات الإكلينيكية تشير إلى نقص مادة الكارنيتين بنوعيها الصر والكلى فى الآطفال الذين تم علاجهم بآدوية علاج الصرع الهرع القديمة وخاصة مادة (صوديوم قالبرويت) . الهدف من الدراسةّ: تقيبم مستوى مادة الكارنيتين بالبالزما فى الآطفال المصابين بالصرع غير معروف العبب والذين تم علاجهم بالآدوية المضادة للمبرع.

طرق البحث: شملت هذه الدراسة خمسين طفل مصابين بالصرع مجهول السبب من كلا الجنسين من عمر عامين وحتى $ه ا$ عام وتم

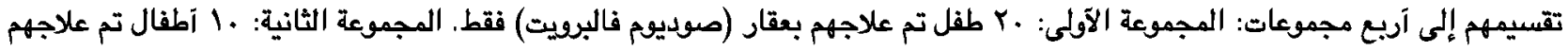

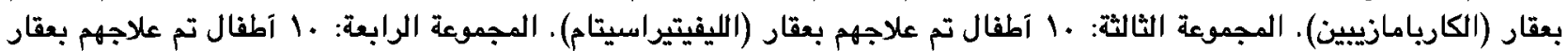

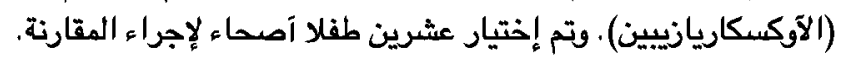

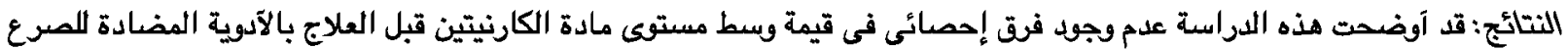

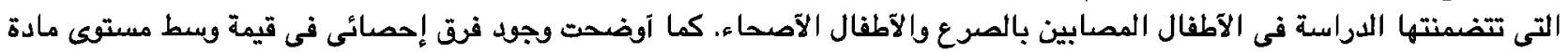

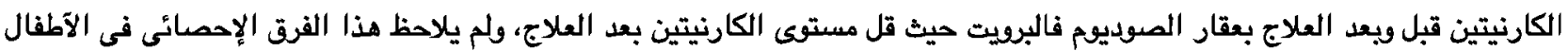

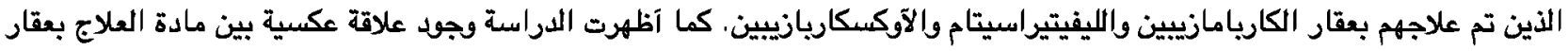

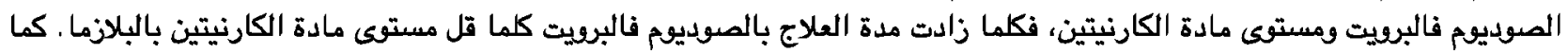

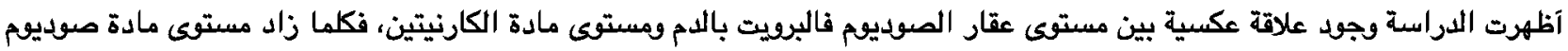

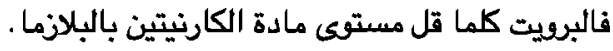
الإستتاج: عقار (الصوديوم فالبريت) هو العلاج الوحيد المضاد الصرع الذى يسبب نقص مادة الكارنيتين بالبلازما . 